\title{
Radiometric Reflectance Measurements of Northern Great Plains Rangeland and Crested Wheatgrass Pastures
}

\author{
J.K. AASE, A.B. FRANK, AND R.J. LORENZ
}

Abstract

Calculated reflectance factors and vegetation indices derived from radiometric reflectance measurements were used in regression analyses to test for a single relationship between canopy reflectance characteristics and measured vegetation parameters from 1 moderately grazed and 1 heavily grazed native rangeland pastures and 1 crested wheatgrass [Agropyron desertorum (Fisch. ex Link) J.A. Schultes] pasture. The study was located on a Williams loam (fine-loamy mixed, Typic Argiboroll) near Mandan, North Dakota. Reflectance measurements were made near solar noon once a week during the 1983 and 1984 growing seasons. There was a statistically significant relationship $\left(r=0.76^{*+}\right)$ between leaf area index and dry green matter among pastures and years. However, each pasture exhibited a unique relationship (statistically significant) between vegetation indices developed from the reflectance measurements and leaf area index or dry green matter. Based on the techniques and wavebands used in this study, over a given geographic region and with pasture management practices known, it may be possible to remotely estimate green dry matter.

Key words: remote sensing, vegetation indices, mixed prairie.

Remotely sensed spectral measurements of grassland ecosystems may provide a rapid and nondestructive estimate of herbage production. Tucker et al. $(1983,1985)$ found a strong relationship $\left(r^{2}=0.75\right)$ between the normalized difference index (based on handheld radiometer readings) and above-ground total dry green matter and between integrated NOAA-7 data, expressed as the normalized difference index, and end-of-season above-ground total dry matter in the Senegalese Sahel $\left(r^{2}=0.69\right)$. They concluded that variable species composition had no bearing on the relationship between vegetation indices derived from spectral radiation measurements and green leaf phytomass.

Tucker (1977a, b), Tucker et al. (1975), and Pearson et al. (1976) working with essentially a monoculture of blue grama [Bouteloua gracilis (H.B.K) Lag ex Griffiths] (SCS 1982)' found that the 0.63 to $0.69 \mu \mathrm{m}$ (red) waveband region showed the most sensitivity to changes in low herbage levels, whereas the 0.74 to $1.00 \mu \mathrm{m}$ (near infrared) waveband region was best suited to detect changes in moderate to high herbage levels. They demonstrated correlation coefficients of 0.95 to 0.98 between the near infrared (NIR) and red (RED) waveband ratio and undisturbed blue grama dry matter. They warned, however, that their approach to estimating herbage was restricted to grass canopies containing at least $30 \%$ green or live vegetation.

Richardson et al. (1983) worked with Alicia grass (Cynodon spp. L.C. Rich.) and found a poor relationship $\left(r^{2}=0.04\right)$ between the RED reflectance factor and herbage yield, whereas there was a good relationship between the NIR reflectance factor $\left(r^{2}=0.73\right)$, the NIR/RED ratio $\left(r^{2}=0.61\right)$, the perpendicular vegetation index (PVI) (Richardson and Wiegand 1977) $\left(r^{2}=0.68\right)$ and herbage production. Ripple (1985), working with tall fescue grass (Festuca arundinacea Schreb.), likewise found good relationships among

\footnotetext{
Authors are soil scientist, USDA-ARS, P.O. Box 1109 , Sidney, Montana 59270; and plant physiologist and agronomist (retired), USDA-ARS, P.O. Box 459, Mandan, North Dakota 58554, respectively.

This article is a contribution from USDA, Agricultural Research Service, Sidney, Montana, and Mandan, North Dakota.

The authors wish to acknowledge the help of Mr. C.A. Klein with field work and data analyses.

Manuscript accepted 11 March 1987.
}

IAll plant names and authorities are from this reference.
Thematic Mapper band reflectances and grass canopy variables $(r \geq 0.80)$. The relationships between herbage and spectral bands and band ratio transformations were curvilinear because of the asymptotic nature of spectral response for moderate and high herbage levels (Tucker, 1977a).

Asrar et al. (1986) estimated intercepted photosynthetically active radiation and leaf area index from multispectral reflectance measurements of native bluestem (Andropogon spp. L.) prairie. They found a greenness transformation to be more useful than the NIR/RED ratio or normalized difference index.

Our objective was to test for 1 relationship between vegetation indices, derived from radiometric reflectance measurements, and green herbage yields from 2 differently managed native mixed prairie pastures and a crested wheatgrass [Agropyron desertorum (Fisch. ex Link) J.A. Schultes] pasture.

\section{Materials and Methods}

The study was conducted on a crested wheatgrass pasture and on both a moderately and heavily grazed native mixed prairie near Mandan, North Dakota $\left(40^{\circ} 46^{\prime} \mathrm{N}, 100^{\circ} 55^{\prime} \mathrm{W}\right)$ during 1983 and 1984. The April through September rainfall was $15.2 \mathrm{~cm}$ in 1983 and $27.1 \mathrm{~cm}$ in 1984 . The soil was a Williams loam (fine-loamy mixed, Typic Argiboroll). The crested wheatgrass pasture was a 15-year-old stand that was grazed by 1 steer $/ 0.5$ ha from 5 May to 8 July 1983 and by 1 sheep/0.1 ha from 10 May to 28 June 1984 . The moderately grazed native pasture was a typical northern Great Plains mixed prairie site that was grazed with yearling steers at 1 steer/3.2 ha from 18 May to 5 October 1983 and from 23 May to 3 October 1984. Primary cover composition as determined at the end of August 1984 by first hits, using the point frame technique (Levey and Madden 1933) was $13 \%$ blue grama, $10 \%$ threadleaf sedge (Carex filifolia Nutt.), 9\% yellow sedge (Carex pennsylvanica Lam.), 5\% needleandthread (Stipa comata Trin. and Rupr.), 4\% western wheatgrass (Agropyron smithii Rydb.), $4 \%$ prairie junegrass [Koeleria pyramidata (Lam.) Beauv.], and $44 \%$ litter. The heavily grazed native pasture was a typical mixed prairie site that had been purposely overgrazed at the intensity of 1 steer $/ 0.9$ ha for the past 70 years. Grazing took place from 5 May to 7 September 1983 and from 23 May to 30 August 1984. Cover composition of the heavily grazed pasture was $34 \%$ blue grama, $35 \%$ litter, and $22 \%$ bare ground.

Herbage samples were collected on a weekly basis from each pasture and for small ungrazed fenced sections within each pasture beginning on 26 April and ending on 13 September 1983 and beginning 10 April and ending 8 August 1984. Herbage was clipped at 3-cm height with a rotary mower from 3 randomly selected $10-X$ 0.9-m-plots on the moderately grazed native and the crested wheatgrass pastures. The remaining stubble was subsampled by hand clipping four $1 / 4-\mathrm{m}^{2}$ areas at the soil surface. All samples were oven dried at $70^{\circ} \mathrm{C}$, weighed, and total dry matter (TDM) calculated on a $\mathrm{g} / \mathrm{m}^{2}$ basis. Three separate $1 / 4-\mathrm{m}^{2}$ areas were hand clipped every week at the soil surface and live separated from dead plant material to determine dry matter of standing green (DG) as well as of standing dead material. Leaf area of the green material was determined by clipping the leaves from the stems and passing all green leaves through a leaf area meter. Leaf area index (LAI) was calculated by dividing the total leaf area by ground area sampled. Because the heavily grazed native pasture was grazed too short to be clipped with a rotary mower, herbage samples were 
Table 1. Linear regression of red (RED), near-lnirared (NIR), and three vegetation indices with total dry matter, green dry matter and leaf area index for a crested wheatgrass pasture.

\begin{tabular}{|c|c|c|c|c|c|c|c|c|c|}
\hline \multirow{2}{*}{$\begin{array}{l}\text { Vegetation } \\
\text { index }\end{array}$} & \multicolumn{3}{|c|}{ Total dry matter $\left(\mathrm{g} / \mathrm{m}^{2}\right)$} & \multicolumn{3}{|c|}{ Dry green matter $\left(\mathrm{g} / \mathrm{m}^{2}\right)$} & \multicolumn{3}{|c|}{ Leaf area index } \\
\hline & Intercept & Slope & $r$ & Intercept & Slope & $r$ & Intercept & Slope & $r$ \\
\hline $\begin{array}{l}\text { RED } \\
\text { NIR } \\
\text { R } \\
\text { ND } \\
\text { GN }\end{array}$ & $\begin{array}{r}120.5 \\
58.6 \\
28.1 \\
31.4 \\
118.8\end{array}$ & $\begin{array}{r}12.3 \\
8.8 \\
52.5 \\
300.1 \\
22.6\end{array}$ & $\begin{array}{l}0.14 \\
0.49 \\
0.49 \\
0.48 \\
0.40\end{array}$ & $\begin{array}{r}25.4 \\
1.6 \\
-3.4 \\
0.0 \\
59.0\end{array}$ & $\begin{array}{r}1983- \\
25.8 \\
8.5 \\
40.3 \\
228.5 \\
22.3\end{array}$ & $\begin{array}{l}0.32 \\
0.58^{*} \\
0.46 \\
0.45 \\
0.49\end{array}$ & $\begin{array}{l}-0.12 \\
-0.82 \\
-1.13 \\
-1.09 \\
-0.09\end{array}$ & $\begin{array}{l}0.22 \\
0.21 \\
0.67 \\
3.87 \\
0.38\end{array}$ & $\begin{array}{l}0.30 \\
0.88^{* *} \\
0.81^{* *} \\
0.81^{* *} \\
0.88^{* *}\end{array}$ \\
\hline $\begin{array}{l}\text { RED } \\
\text { NIR } \\
\text { R } \\
\text { ND } \\
\text { GN }\end{array}$ & $\begin{array}{l}159.8 \\
322.7 \\
209.6 \\
230.9 \\
198.8\end{array}$ & $\begin{array}{r}2.0 \\
-12.8 \\
-15.8 \\
-141.5 \\
-17.0\end{array}$ & $\begin{array}{l}0.00 \\
0.35 \\
0.20 \\
0.24 \\
0.24\end{array}$ & $\begin{array}{r}57.3 \\
281.8 \\
203.1 \\
221.5 \\
171.4\end{array}$ & $\begin{array}{r}1984--129.8 \\
-12.9 \\
-28.1 \\
-209.9 \\
24.0\end{array}$ & $\begin{array}{l}0.33 \\
0.53 \\
0.53 \\
0.17 \\
0.50\end{array}$ & $\begin{array}{r}1.97 \\
-0.50 \\
-0.33 \\
-0.57 \\
0.22\end{array}$ & $\begin{array}{r}-0.58 \\
0.10 \\
0.36 \\
2.69 \\
0.23\end{array}$ & $\begin{array}{l}0.71^{*} \\
0.45 \\
0.75^{*} \\
0.79^{*} \\
0.55\end{array}$ \\
\hline $\begin{array}{l}\text { RED } \\
\text { NIR } \\
\text { R } \\
\text { ND } \\
\text { GN }\end{array}$ & $\begin{array}{l}165.4 \\
112.6 \\
137.1 \\
134.8 \\
145.2\end{array}$ & $\begin{array}{r}-3.6 \\
3.9 \\
7.7 \\
51.3 \\
6.9\end{array}$ & $\begin{array}{l}0.00 \\
0.17 \\
0.10 \\
0.10 \\
0.10\end{array}$ & $\begin{array}{r}110.7 \\
30.1 \\
81.3 \\
76.3 \\
85.6\end{array}$ & $\begin{array}{r}-3.0 \\
6.5 \\
8.7 \\
63.6 \\
10.6\end{array}$ & $\begin{array}{l}0.00 \\
0.36 \\
0.14 \\
0.14 \\
0.22\end{array}$ & $\begin{array}{r}1.22 \\
-0.80 \\
-0.58 \\
0.80 \\
-0.00\end{array}$ & $\begin{array}{l}0.27 \\
0.12 \\
0.44 \\
3.16 \\
0.33\end{array}$ & $\begin{array}{l}0.37 \\
0.76^{* *} \\
0.80^{* *} \\
0.82^{* *} \\
0.77^{* *}\end{array}$ \\
\hline
\end{tabular}

R = NIR $/$ RED, ND = Normalized difference vegetation index, $G N=$ greenness index.

$*, * *$ Significant at 0.05 and 0.01 levels, respectively.

obtained by hand clipping at the soil surface. Samples were processed as for the other 2 pastures.

Five permanent random plots in each pasture were selected for radiometric reflectance measurements with an Ideas Inc. Mark-II ${ }^{2}$ radiometer having a $24^{\circ}$ field of view. A bare soil plot was prepared in each pasture and also included in the radiometric measurements. The radiometer was mounted on a mast placed in permanently secured pipes in the soil, and both RED $(0.63$ to $0.69 \mu \mathrm{m})$ and NIR $(0.76$ to $0.90 \mu \mathrm{m})$ waveband measurements in $\mathrm{W} / \mathrm{m}^{2}$ were obtained from a height of $2 \mathrm{~m}$ above the soil surface. Five readings were taken from each plot and averaged. The radiometer was calibrated prior to each set of readings in each pasture by measuring reflectance from a painted barium sulfate plate. The radiometric measurements were made once a week near solar noon. We calculated reflectance factors from the RED and NIR radiometric readings and calculated the ratio vegetation index (R=NIR/RED), the normalized difference vegetation index [ND $=($ NIR-RED)/(NIR+ RED)] and greenness (GN) as described by Jackson (1983). The refelectance factors and vegetation indices were used in regression analyses to determine relationships between canopy reflectance characteristics and measured vegetation parameters. On 13 June, 2

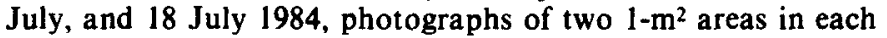
pasture were taken with a nadir-oriented camera to estimate ground cover.

\section{Results and Discussion}

Total DG on the 2 grazed native rangeland pastures generally followed the same pattern for 2 years (Fig. 1 and 2). The DG from the heavily grazed pasture peaked at about $60 \mathrm{~g} / \mathrm{m}^{2}$ in both years and from the moderately grazed pasture at about 130 and $150 \mathrm{~g} / \mathrm{m}^{2}$ in 1983 and 1984, respectively. The crested wheatgrass pasture responded somewhat differently in 1984 than in 1983 with a herbage regrowth period after the grazing period in 1984. Average peak total DG across the 2 years for the ungrazed portion of each pasture was about 350,125 , and $85 \mathrm{~g} / \mathrm{m}^{2}$ for crested wheatgrass, moderately grazed, and heavily grazed pastures, respectively (data not presented).

As herbage yield increases, red radiance decreases and nearinfrared radiance increases. With minimal vegetation covering the

${ }^{2}$ Trade and company names are included for the benefit of the reader and imply no endorsement of preferential treatment by the USDA of the product used.

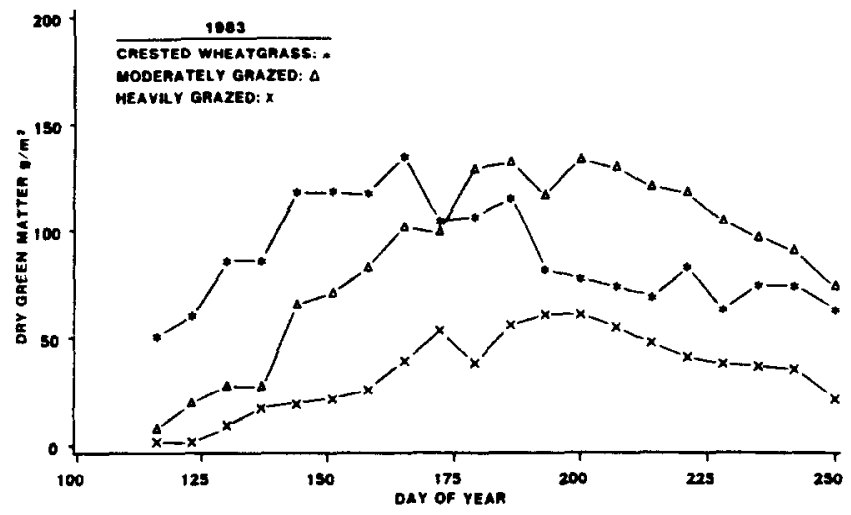

Fig. 1. Time progression of dry green matter in 1983 for crested wheatgrass, moderately grazed native, and heavily grazed native rangeland pastures.

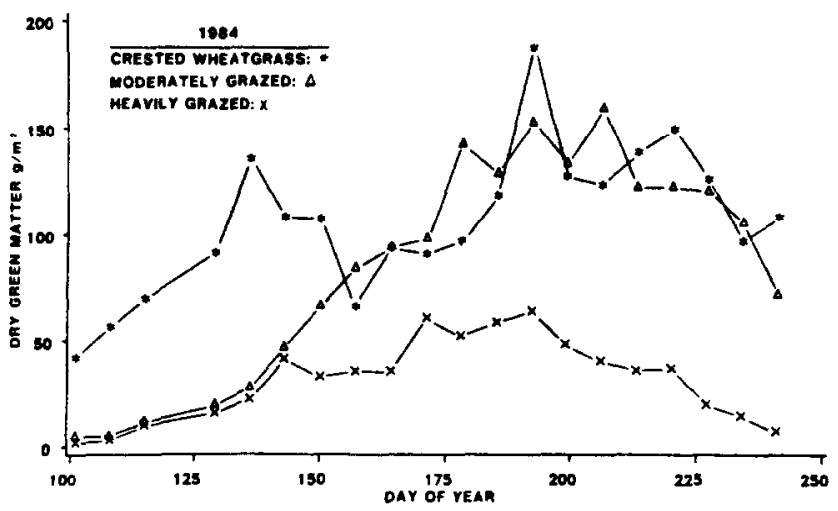

Fig. 2. Time progression of dry green matter in 1984 for crested wheatgrass, moderately grazed native, and heavily grazed native rangeland pastures.

soil surface, radiation from the soil will dominate and mask the vegetation response. Richardson and Wiegand (1977) demonstrated that on a graph of NIR vs. RED reflectance values, the 
Table 2. Linear regression of red (RED), near-infrared (NIR), and three vezetation indices with total dry matter, green dry matter and leaf area index for a moderately grazed native pasture.

\begin{tabular}{|c|c|c|c|c|c|c|c|c|c|}
\hline \multirow{2}{*}{$\begin{array}{l}\text { Vegetation } \\
\text { index }\end{array}$} & \multicolumn{3}{|c|}{ Total dry matter $\left(\mathrm{g} / \mathrm{m}^{2}\right)$} & \multicolumn{3}{|c|}{ Dry green matter $\left(\mathrm{g} / \mathrm{m}^{2}\right)$} & \multicolumn{3}{|c|}{ Leaf area index } \\
\hline & Intercept & Slope & $r$ & Intercept & Slope & $r$ & Intercept & Slope & $r$ \\
\hline $\begin{array}{l}\text { RED } \\
\text { NIR } \\
\text { R } \\
\text { ND } \\
\text { GN }\end{array}$ & $\begin{array}{l}342.6 \\
286.1 \\
150.4 \\
155.0 \\
207.1\end{array}$ & $\begin{array}{r}-42.1 \\
-4.4 \\
37.6 \\
215.9 \\
28.6\end{array}$ & $\begin{array}{l}0.84^{* *} \\
0.17 \\
0.74^{* *} \\
0.77^{* *} \\
0.61 *\end{array}$ & $\begin{array}{r}223.9 \\
74.6 \\
-49.7 \\
-39.6 \\
32.7\end{array}$ & $\begin{array}{r}1983 \\
-55.6 \\
2.0 \\
57.5 \\
323.2 \\
47.2\end{array}$ & $\begin{array}{l}0.89^{* *} \\
0.00 \\
0.92^{* *} \\
0.94^{* *} \\
0.81^{* *}\end{array}$ & $\begin{array}{r}1.06 \\
-0.22 \\
-0.39 \\
-0.31 \\
0.05\end{array}$ & $\begin{array}{r}-0.26 \\
0.07 \\
0.34 \\
1.83 \\
0.30\end{array}$ & $\begin{array}{l}0.74^{* *} \\
0.36 \\
0.93^{* *} \\
0.92^{* *} \\
0.91^{* *}\end{array}$ \\
\hline $\begin{array}{l}\text { RED } \\
\text { NIR } \\
\text { R } \\
\text { ND } \\
\text { GN }\end{array}$ & $\begin{array}{r}468.4 \\
80.1 \\
171.0 \\
170.9 \\
227.7\end{array}$ & $\begin{array}{r}-87.2 \\
18.2 \\
42.4 \\
255.4 \\
34.3\end{array}$ & $\begin{array}{l}0.82^{* *} \\
0.60 \\
0.71^{*} \\
0.76^{*} \\
0.67^{*}\end{array}$ & $\begin{array}{r}422.4 \\
-259.6 \\
-89.4 \\
-85.2 \\
7.2\end{array}$ & $\begin{array}{r}-1984 \\
-145.6 \\
33.6 \\
77.0 \\
453.5 \\
67.1\end{array}$ & $\begin{array}{l}0.90^{* *} \\
0.72^{*} \\
0.84^{* *} \\
0.89^{* *} \\
0.86^{* *}\end{array}$ & $\begin{array}{r}2.24 \\
-1.81 \\
-0.63 \\
-0.58 \\
-0.05\end{array}$ & $\begin{array}{r}-0.79 \\
0.22 \\
0.46 \\
2.62 \\
0.39\end{array}$ & $\begin{array}{l}0.93^{* *} \\
0.88^{* *} \\
0.96^{* *} \\
0.98^{* *} \\
0.96^{* *}\end{array}$ \\
\hline $\begin{array}{l}\text { RED } \\
\text { NIR } \\
\text { R } \\
\text { ND } \\
\text { GN }\end{array}$ & $\begin{array}{l}375.1 \\
165.5 \\
160.6 \\
162.9 \\
212.6\end{array}$ & $\begin{array}{r}-52.0 \\
9.0 \\
38.4 \\
226.1 \\
32.5\end{array}$ & $\begin{array}{l}0.75^{* *} \\
0.32 \\
0.62^{* *} \\
0.67^{* *} \\
0.59^{* *}\end{array}$ & $\begin{array}{r}252.6 \\
-23.4 \\
-63.1 \\
-54.8 \\
23.1\end{array}$ & $\begin{array}{r}-68.3 \\
11.9 \\
64.2 \\
367.2 \\
55.0\end{array}$ & $\begin{array}{l}0.82^{* *} \\
0.35 \\
0.87^{* *} \\
0.89^{* *} \\
0.82^{* *}\end{array}$ & $\begin{array}{r}1.25 \\
-0.62 \\
-0.47 \\
-0.40 \\
0.01\end{array}$ & $\begin{array}{r}-0.34 \\
0.11 \\
0.38 \\
2.10 \\
0.34\end{array}$ & $\begin{array}{l}0.74^{* *} \\
0.57^{* *} \\
0.92^{* *} \\
0.93^{* *} \\
0.93^{* *}\end{array}$ \\
\hline
\end{tabular}

$R=N I R / R E D, N D=$ Normalized difference vegetation index, $G N=$ greenness index.

*,**Significant at 0.05 and 0.01 levels, respectively.

values for vegetation were either near a straight line, called the soil line, or above that line. The perpendicular distance from the soil line to a vegetation observation point is a measure of herbage yield. Because our pastures had a large percentage of litter and bare soil, and since litter reflectance cannot easily be distinguished from bare soil reflectance (Aase and Tanaka 1984), we plotted such a soil line based on the bare soil measurements along with the data points from the 3 pastures from both years (Fig. 3). Some of the data

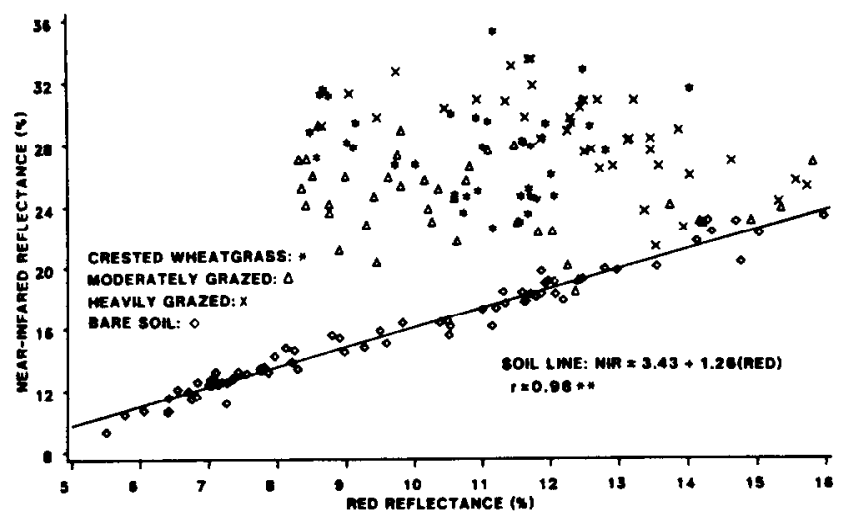

Fig. 3. The soil line and vegetation points from crested wheatgrass and moderately and heavily grazed native rangeland pastures.

points from the moderately and heavily grazed pastures were adjacent to the soil line so that they could not be distinguished from it. However, most of the data points are above the soil line suggesting that from about 16 to $63 \mathrm{~g} / \mathrm{m}^{2}$ was enough DG for the heavily and moderately grazed pastures, respectively, to mask most of the litter and soil background. The data points for crested wheatgrass pasture represent more than $60 \mathrm{~g} / \mathrm{m}^{2}$.

The DG and leaf area data from all pastures and both years were combined (Fig. 4) and a common relationship derived for LAI versus DG where

$$
\mathrm{LAI}=0.021+0.005(\mathrm{DG}) \quad r=0.76
$$

Crested wheatgrass is a bunch grass and some of the scatter in the data from the crested wheatgrass pasture can be ascribed to greater sample variation due to less uniformity of plant cover in that

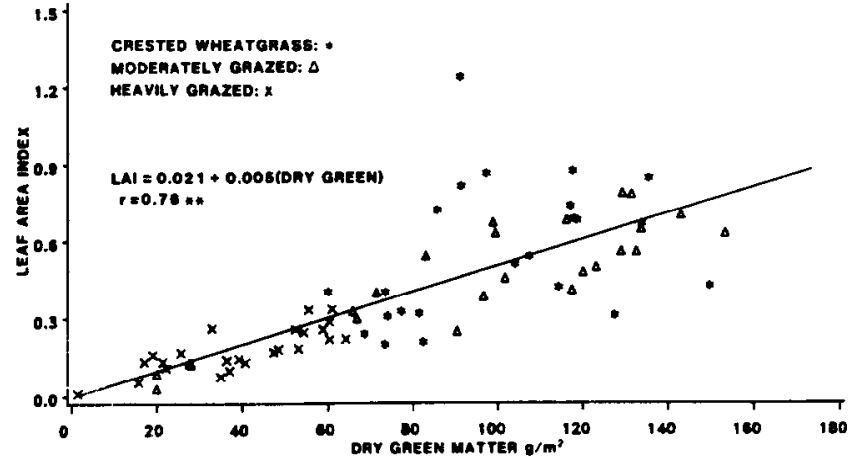

Fis. 4. Relationship between leaf area index and dry green matter for crested wheatgrass and moderately and heavily grazed native rangeland pastures.

pasture than in the other 2 pastures. The equation for only the moderately and heavily grazed mixed prairie pastures is

$$
\mathrm{LAI}=0.008+0.005(\mathrm{DG}) \quad r=0.92
$$

The griater sample variation in the crested wheatgrass pasture is also evident from the generally lower $r$ values in Table 1 as compared with those from the moderately and heavily grazed pastures (Tables 2 and 3).

Among the reflectance parameters tested, ND in general related best to TDM, DG, and LAI, except for TDM and DG for crested wheatgrass, which showed little if any relationship to any of the reflectance parameters tested (Tables 1, 2,3). The greenness vegetation index does not correlate as well with vegetation parameters when only 2 wavebands are used in the calculations as it does with the addition of other bands (Jackson 1983). Nevertheless, particularly on the moderately grazed pasture, it compared favorably with ND and $R$ as related to LAI.

Although the LAI vs. DG relationship was constant among years and pastures (Fig. 4), there was no such constancy among vegetation parameters and vegetation indices. To illustrate, we show the relationship, with data from both years combined, 
Table 3. Linear regression of red (RED), near-infrared (NIR), and three vezetation indices with total dry matter, green dry matter and leaf area index for a heavily grazed pasture.

\begin{tabular}{|c|c|c|c|c|c|c|c|c|c|}
\hline \multirow{2}{*}{$\begin{array}{l}\text { Vegetation } \\
\text { index }\end{array}$} & \multicolumn{3}{|c|}{ Total dry matter $\left(\mathrm{g} / \mathrm{m}^{2}\right)$} & \multicolumn{3}{|c|}{ Dry green matter $\left(\mathrm{g} / \mathrm{m}^{2}\right)$} & \multicolumn{3}{|c|}{ Leaf area index } \\
\hline & Intercept & Slope & $r$ & Intercept & Slope & $r$ & Intercept & Slope & $r$ \\
\hline & & & & & -1983 & & & & \\
\hline RFD & 154.7 & -32.3 & $0.68 * *$ & 152.4 & -40.2 & $0.81 * *$ & 0.68 & -0.18 & $0.82^{* *}$ \\
\hline NIR & -45.1 & 9.1 & $0.58^{*}$ & -59.0 & 8.2 & $0.51^{*}$ & -0.32 & 0.04 & $0.58^{*}$ \\
\hline $\mathbf{R}$ & -9.6 & 29.8 & $0.79 * *$ & -42.7 & 33.2 & $0.84^{* *}$ & -0.21 & 0.16 & $0.91^{* * *}$ \\
\hline ND & -6.6 & 170.7 & $0.79^{* *}$ & -40.9 & 193.4 & $0.86^{* *}$ & -0.19 & 0.89 & $0.89^{* * *}$ \\
\hline GN & 31.7 & 17.9 & $0.74^{* *}$ & 4.2 & 19.4 & $0.77^{* *}$ & -0.01 & 0.09 & $0.82^{* *}$ \\
\hline RED & 164.4 & -39.1 & $0.75^{* *}$ & 134.9 & $\begin{array}{r}-1984- \\
-36.6\end{array}$ & $0.77^{*}$ & 0.65 & -0.18 & $0.71^{*}$ \\
\hline NIR & -108.1 & 13.9 & $0.85^{* *}$ & -127.1 & 13.6 & $0.89 * *$ & -0.65 & 0.07 & $0.84^{* *}$ \\
\hline $\mathbf{R}$ & 4.3 & 24.4 & $0.79 * *$ & -15.9 & 23.1 & $0.81 * *$ & -0.11 & 0.12 & $0.79^{*}$ \\
\hline ND & $-\quad 3.7$ & 166.1 & $0.84^{* *}$ & -23.7 & 158.0 & $0.86^{* *}$ & -0.14 & 0.80 & $0.82^{* * *}$ \\
\hline GN & 29.3 & 20.5 & $0.79 * *$ & 6.3 & 20.2 & $0.85^{* *}$ & 0.01 & 0.10 & $0.81^{* *}$ \\
\hline RED & 146.6 & -30.3 & $0.68 * *$ & 133.4 & $\begin{array}{c}\text { mbined-- } \\
-34.5\end{array}$ & $0.77^{* *}$ & 0.61 & -0.16 & $0.76^{* *}$ \\
\hline NIR & -61.6 & 10.4 & $0.69^{* *}$ & -80.7 & 10.0 & $0.66^{* *}$ & -0.42 & 0.05 & $0.69^{* *}$ \\
\hline $\mathbf{R}$ & $-\quad 2.8$ & 27.1 & $0.79^{* *}$ & -30.2 & 28.3 & $0.82^{* *}$ & -0.16 & 0.14 & $0.85^{* *}$ \\
\hline ND & $-\quad 5.7$ & 169.3 & $0.81^{* *}$ & -34.1 & 179.1 & $0.86^{* *}$ & -0.17 & 0.85 & $0.87^{* *}$ \\
\hline GN & 30.6 & 19.0 & $0.76^{* *}$ & 4.6 & 19.9 & $0.80^{* *}$ & 0.01 & 0.10 & $0.82 * *$ \\
\hline
\end{tabular}

$R=$ NIR $/$ RED,$N D=$ Normalized difference vegetation index. $G N=$ greenness index .

*,**Significant at 0.05 and 0.01 levels, respectively.

between LAI and ND for the 3 pastures in Figure 5. We chose the LAI relationship because of its generally good relationship with ND on all 3 pastures. Testing the regression equations representing the data from the 3 pastures showed that the slopes differed significantly from each other $(P=0.01)$. We cannot use 1 relationship between a vegetation index and LAI (or DG) for the 3 pastures to obtain a measure of herbage yield from remote measurements.

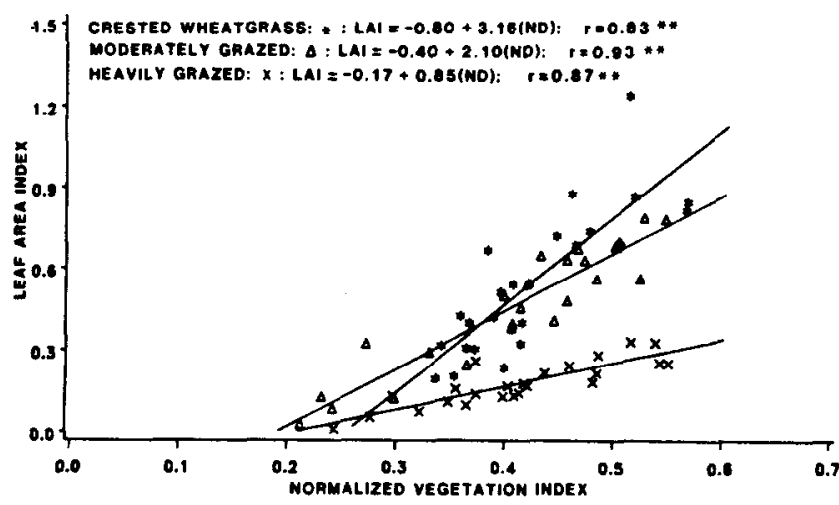

Fig. 5. Relationship between leaf area index and normalized vegetation index for crested wheatgrass and moderately and heavily grazed native rangeland pastures.

This is particularly true as the standing crop nears maximum yield. As shown in Figure 5, a ND of 0.5 would result in LAI of about $0.25,0.65$, and 0.78 for heavily grazed, moderately grazed, and crested wheatgrass pastures, respectively. However, with prior knowledge of management practices it may be possible, within a given geographic region, to establish meaningful relationships such as those shown in Figure 5 to predict herbage yields of rangeland.

Reasons for the similar response of the radiometer to 3 different DG levels can probably be explained by the growth habits of the 3 pastures. For example, although minimal DG was obtained from the heavily grazed pasture, the dense growth habit of blue grama produced a ground cover nearly equal to that of the crested wheatgrass and moderately grazed mixed prairie pastures. That this was so was suggested by a visual estimate of ground cover from the photographs taken with the nadir-oriented camera during the summer of 1984.

\section{Conclusions}

Regardless of management practice, 1 relationship existed between LAI and DG. However, relationships between LAI (or DG) and vegetation indices calculated from radiometric measurements differed for each of the 3 pastures used in the study. Therefore, the implications are that management practices must be known, and relationships between vegetation indices and herbage yield from individual pastures for a given geographical region must be established before herbage yields can be estimated with any degree of certainty using remote measurements and wavebands as described in this study.

\section{Literature Cited}

Aase, J.K., and D.L. Tanaka. 1984. Effects of tillage practices on soil and wheat spectral reflectances. Agron. J. 76:814-818.

Asrar, G., E.T. Kanemasu, G.P. Miller, and R.L. Weiser. 1986, Light interception and leaf area estimates from measurements of grass canopy reflectance. IEEE Trans. Geosci. Remote Sensing GE-24:76-82.

Jackson, R.D. 1983. Spectral indices in n-Space. Remote Sensing Environ. 13:409-421.

Levey, E.B., and E.A. Madden. 1933. The point method of pasture analyses. N.Z.J. Agr. 46:267-279.

Pearson, R.L., C.J. Tucker, and L.D. Miller. 1976. Spectral mapping of shortgrass prairie biomass. Photogram. Eng. Remote Sensing 42:317-323.

Richardson, A.J., and C.L. Wiegand. 1977. Distinguishing vegetation from soil background information. Photogram. Eng. Remote Sensing 43:15411552.

Richardson, A.J., J.H. Everitt, and H.W. Gausman. 1983. Radiometric estimation of biomass and nitrogen content of Alicia grass. Remote Sensing Environ. 13:179-184.

Ripple, W.J. 1985. Landsat Thematic Mapper bands for characterizing fescue grass vegetation. Int. J. Remote Sensing 6:1373-1384.

Soil Conservation Service. 1982. National list of scientific plant names. Vol. 1. List of plant names. USDA, SCS-TP-159. U.S. Government Printing Office, Washington, DC.

Tucker, C.J., L.D. Miller, and R.L. Pearson. 1975. Shortgrass prairie spect ral measurements. Photogram. Eng. Remote Sensing 41:1157-1162.

Tucker, C.J.1977a. Asymptotic nature of grass canopy spectral reflectance. Appl. Opt. 16:1151-1156.

Tucker, C.J. 1977b. Spectral estimation of grass canopy variables. Remote Sensing Environ. 6:11-26.

Tucker, C.J., C. Vanpraet, E. Boerwinkel, and A. Gaston. 1983. Satellite remote sensing of total dry matter production in the Senegalese Sahel. Remote Sensing Environ. 13:461-474.

Tucker, C.J., C.L. Vanpraet, M.J. Sharman, and G. Van Ittersum. 1985. Satellite remote sensing of total herbaceous biomass production in the Senegalese Sahel: 1980-1984. Remote Sensing Environ. 17:233-249. 